\title{
PENERAPAN MODEL DIRECT INSTRUCTIONS UNTUK MENINGKATKAN HASIL BELAJAR PENJASKES
}

\author{
Saiful Anam \\ Sekolah Menengah Pertama Negeri 4 Blitar \\ Jalan Dr. Soetomo Nomor 92 Blitar \\ Sifula6@gmail.com
}

\begin{abstract}
Application Instructions Direct Model to Improve Learning Outcomes PE. This study aims to determine the effectiveness of the implementation of Direct models Insructions in improving the process and learning outcomes of students of class VII B SMP Negeri 4 Blitar. Classroom action research for two cycles with research subjects totaling 34 students. Instruments of data collection using observation sheet teachers and students learning activities, tests, field notes, and documentation. Data were analyzed with the following steps: data reduction, exposure data, and drawing conclusions. Results showed through the application of models direct instructions from the first cycle to the second cycle showed increased student learning outcome.
\end{abstract}

Keywords: learning outcomes, soccer, direct instructions

\begin{abstract}
Abstrak:Penerapan Model Direct Instructions untuk Meningkatkan Hasil Belajar Penjaskes. Penelitian ini bertujuan untuk mengetahui keefektifan penerapan model Direct Insructions dalam meningkatkan proses dan hasil belajar siswa kelas VII B SMP Negeri 4 Blitar. Penelitian tindakan kelas selama dua siklus dengan subyek penelitian berjumlah 34 siswa. Instrumen pengumpulan data menggunakan lembar observasi kegiatan pembelajaran guru dan siswa, tes, catatan lapangan, dan dokumentasi. Data dianalisis dengan langkah-langkah: reduksi data, paparan data, dan penarikan kesimpulan. Hasil penelitian menunjukkan melalui penerapan model direct instructions dari siklus pertama ke siklus kedua menujukkan peningkatan hasil belajar siswa meningkat.
\end{abstract}

Kata kunci: hasil belajar, sepak bola, direct instructions

Pendidikan jasmani olahraga dan kesehatan memiliki peran yang sangat penting dalam mengidentifikasikan penyelenggaraan pendidikan sebagai suatu proses pembelajaran pendidikan sebagai suatu proses pembinaan manusia yang berlangsung seumur hidup. Pendidikan jasmani olahraga dan kesehatan memberikan kesempatan kepada siswa untuk terlibat langsung dalam aneka pengalaman belajar melalui aktifitas jasmani, bermain dan berolahraga yang dilakukan secara sistematis terarah dan terlaksana. Pembekalan pengalaman belajar melalui proses pembelajaran pendidikan jasmani olahraga dan kesehatan dengan mengajarkan teori, berbagai keterampilan gerak dasar, tehnik dan setrategi permainan olahraga internalisasi nilai-nilai (sportifitas, kejujuran, kerjasama, dan lain-lain).

Sepak bola merupakan cabang olahraga yang berbentuk permainan dan di dalamnya terdapat beberapa macam keterampilan dasar bermain sepak bola. Selain itu dalam permainan sepak bola diajarkan pula sikap sportifitas. Hal ini sesuai dengan tujuan Pendidikan Nasional yakni mencerdaskan kehidupan bangsa dan mengembangkan manusia Indonesia seutuhnya yang bertaqwa, berbudi pekerti luhur, berpengetahuan, sehat jasmani dan rohani serta berkepribadian mantap dan bertanggung jawab (Sukintaka, 1992:8). 
Pembelajaran sepak bola di SMP Negeri 4 Blitar kelas 7 B banyak terjadi kesalahan seperti menendang bola dengan kaki bagian dalam, bagian luar, dan punggung kaki dilakukan dengan ujung kaki, begitu juga pada saat menghentikan bola semestinya dihentikan dengan kaki bagian dalam, bagian luar, dan punggung kaki dilakukan dengan mata kaki dan saat menggiring bola dengan kaki bagian dalam, bagian luar dan punggung kaki dilakukan dengan ujung kaki, sehingga arah bola menjadi tak terarah, kalau dihubungkan dengan teknik bermain sepak bola belum tercapai, begitu juga pada tingkat pengetahuannya, kompetensi dasar yang menjadi pedoman guru pendidikan jasmani SMP Negeri 4 Blitar dalam mengajar sepak bola belum dapat menunjukkan hasil yang maksimal dapat dilihat dari nilai pengetahuan, keterampilan sepak bola masih banyak siswa yang mendapat nilai di bawah 75 . Untuk penilaian pembelajaran sepak bola, ditetapkan Kriteria Ketuntasan Minimal (KKM) yaitu 75. Pada ulangan harian Penjaskes dengan materi dan teknik-teknik gerakan sepak bola, di dapat 15 siswa dari 34 siswa yang mendapat nilai di atas KKM. Hal ini berarti, hanya $44,11 \%$ dari siswa yang telah mencapai ketuntasan belajar, dan yang lainnya memiliki prestasi belajar yang rendah.

Kemampuan dasar erat sekali hubunganya dengan kemampuan koordinasi gerak fisik, taktik dan mental.Keterampilan dasar harus betulbetul dikuasai dan dipelajari lebih awal untuk mengembangkan mutu permainan. Menurut Sucipto, dkk (2000:17), pemain yang memiliki teknik dasar yang baik cenderung dapat bermain sepak bola dengan baik pula. Menurut Sucipto, dkk (2000: 17), teknik-teknik dasar dalam permainan sepak bola ada beberapa macam, seperti: menendang (kicking), menghentikan (stoping), menggiring (dribbling), menyundul (heading), merampas (tackling), lemparan ke dalam (throwin), dan menjaga gawang (goal keeping).

Berdasarkan hal tersebut, dilakukam diskusi dengan teman sejawat untuk meneliti kekurangan dari pembelajaran yang telah dilaksanakan. Berdasarkan hasil diskusi, ditemukan masalahmasalah dalam proses pembelajaran Penjaskes yang menyebabkan menurunkan prestasi belajar yaitu: (1) materi kurang dapat dikuasi siswa secara optimal; (2) siswa belum dapat melaksanakan ketrampilan dasar sepak bola, siswa kurang sabar dalam melaksanakan ketrampilan dasar dan ingin segera bermain sepak bola; (3) kebanyakan siswa cenderung hanya memakai ingatan akan bermain sepak bola yang mereka ketahui tanpa memperhatikan materi yang telah ada. Mereka merasa binggung dan bosan pada ketrampilan dasar yang diajarkan. Karena dilakukan secara instan, maka kesalahan-kesalahan masalah akibat dari kelupaan pemilihan materi kadang tidak dapat dihindarkan; (4) melihat hasil ulangan harian siswa diatas, bisa dilihat jika penggunaan metode pembelajaran dalam pembelajaran Penjaskes pada siswa kelas VII-B belum membuat siswa terlihat antusias dalam belajar; (5) pembelajaran dengan metode konvensional yaitu dengan menjelaskan materi dan siswa hanya melakukan latihan fisik secara langsung dan memerintahkan siswa langsung bermain sepak bola tanpa penanaman konsep pembelajaran yang kuat ternyata tidak efektif dalam proses peningkatan prestasi belajar siswa.

Setelah melihat hasil analisa di atas dan tukar pendapat dengan teman sejawat, maka untuk memperbaiki berbagai masalah yang ada, peneliti memutuskan dengan menggunakan Model Pembelajaran Direct Instructions dalam pembelajaran Penjaskes ini. Strategi direct instructions adalah model pembelajaran langsung dikembangkan secara khusus untuk meningkatkan proses pembelajaran para siswa terutama dalam hal memahami sesuatu (pengetahuan) dan menjelaskannya secara utuh yang diajarkan secara bertahap, sehingga prestasi belajar siswa pun dapat meningkat.

\section{METODE}

Lokasi yang digunakan tempat penelitian adalah kelas VII-B SMP Negeri 4 Blitar Tahun pelajaran 2015/2016. Subjek yang digunakan adalah seluruh siswa kelas VII-B SMP Negeri 4 Blitar tahun pelajaran 2015/2016 sebanyak 34 siswa yang terdiri dari 18 siswa putra dan 16 siswa putri. Observer terdiri atas dua orang Guru yaitu, Bapak Saiful Anam, S.Pd dan Bapak Sugeng Meilana, S.Pd yang membantu peneliti dalam merekam proses pembelajaran dengan instrumen yang dipilih. 
Berdasarkan variabel yang diteliti dan tujuan yang hendak dicapai, maka metode penelitian yang digunakan adalah dengan sistem spiral. Stephen Kemmis dan Robin Mc Taggart (1988) mengembangkan model Kurt Lewin dalam suatu sistem spiral dengan empat komponen utama, yakni perencanaan (planning), tindakan (acting), observasi (observing) dan refleksi (reflecting). Namun yang membedakan dengan Kurt Lewin adalah sesudah suatu siklus selesai, yakni sesudah refleksi kemudian diikuti dengan adanya perencanaan ulang yang dilaksanakan dalam bentuk siklus tersendiri, demikian seterusnya dengan beberapa kali siklus.

Rencana tindakan: (1) mempersiapkan instrumen penilaian untuk merekam dan menganalisis data; (2) mempersiapkan bahan ajar, Rencana Pelaksaan Pembelajaran (RPP), tugas-tugas kelompok, kuis dan lembar observasi, instrumen lain, jurnal kegiatan, angket dan lain-lain; (3) mengajak siswa untuk ke lapangan sekolah, dan memerintahkan masing-masing anggota kelompok untuk saling berpasangan untuk melaksanakan kegiatan pembelajaran

Pelaksanaan tindakan: (1) siswa diberi penjelasan tentang pembelajaran direct instructions dan komponen-komponennya; (2) guru memberikan penjelasan tentang tujuan pembelajaran dan garis besar materi dan teknik sepak bola;(3) guru membagi tugas kepada setiap kelompok. Setiap anggota kelompok saling berpasangan dan memperagakan gerakan dasar sepakbola; (4) guru memberikan post test untuk mengukur keberhasilan yang dicapai siswa, sehingga bisa dilihat peningkatan prestasi belajar siswa.

Observasi selama tahap pelaksanaan, peneliti melakukan observasi terhadap ketrampilan kooperatif yang dilatihkan kepada siswa dengan menggunakan lembar observasi yang telah disiapkan. Kegiatan observasi siklus pertama dilakukan bersamaan dengan pelaksanaan tindakan siklus pertama. Pada tahap ini peneliti mengacu pada langkah-langkah pembelajaran direct instructions, yaitu: (1) guru menyampaikan kompetensi yang ingin dicapai; (2) mereview pengetahuan dan keterampilan prasyarat; (3) guru menyampaikan materi pelajaran/demonstran; (4) guru melaksanakan bimbingan; (5) guru member kesempatan pada siswa untuk berlatih; (6) menilai kenerja siswa dan member umpan balik; (7) memberikan latihan mandiri. Untuk kegiatan observasi, dicatat pula gagasan-gagasan dan kesankesan yang muncul dan segala sesuatu yang benar terjadi dalam proses pembelajaran. Jadi observasi ini dilakukan adalah untuk mengamati berbagai hal selama pembelajaran, mengamati interaksi selama proses penyelidikan berlangsung dan mengamati respon siswa terhadap proses pembelajaran.

Refleksi tindakanguru menyampaikan tujuan dan manfaat dari materi dan teknik-teknik gerakan sepak bola pada siswa sebelum pelajaran dimulai, dan memberikan apersepsi kepada siswa sebagai pemanasan. Untuk itu, dibentuklah kelompok agar siswa dapat bekerjasama dengan siswa lain dalam memperagakan teknik yang ada dan diakhiri dengan post-test dan indikator tercapai bila $85 \%$ dari siswa kelas VII-B mendapat nilai Penjaskes minimal di atas KKM atau 75.

Instrumen penelitian adalah alat atau sarana yang digunakan oleh peneliti untuk mengumpulkan data penelitian. Data penelitian yang dimaksud adalah sebuah informasi dari penelitian tindakan kelas ini, yaitu berupa kata-kata, angka-angka, gambar, segala sesuatu yang dapat digunakan untuk menjawab masalah penelitian, instrumen yang digunakan dalam penelitian ini adalah RPP, lembar observasi, catatan lapangan, tes, penilaian sikap.

Teknik analisis data yang digunakan yaitu deskriptif persentase. Data hasil penelitian yang dianalisis meliputi: ketuntasan belajar individu dan ketuntasan belajar secara klasikal. Hasil ini diinterprestasikan dan disimpulkanuntuk menjawab permasalahan yang ada. Data hasil observasi guru dan siswa keterlaksanaan pembelajaran melalui pembelajaran direct instructions dan observasi aktivitas siswa dianalisis secara deskriptif untuk memberikan gambaran pelaksanaan pembelajaran dengan menggunakan pembelajaran direct instructions.

Data hasil nilai sikap yang diambil adalah nilai modus atau yang sering muncul pada saat pembelajaran berlangsung. Data hasil nilai ketrampilan yang diambil adalah nilai optimum dari siswa pada saat pembelajaran berlangsung. Hasil wawancara dengan siswa dianalisis secara deskriptif dengan lembar angket untuk mengetahui pendapat guru dan siswa terhadap pembelajaran. Berdasarkan hasil tes siswa, setiap teknik yang 
diperagakan siswa diberi skor kemudian diperoleh nilai untuk setiap siswa.

Tabel 1 Kualifikasi Tingkat Prestasi Belajar Penjaskes Siswa

\begin{tabular}{cc}
\hline $\begin{array}{c}\text { Persentase }(\%) \text { tingkat ketun- } \\
\text { tasan belajar Penjaskes siswa }\end{array}$ & Ketegori \\
\hline $85,00 \%<x \leq 100 \%$ & Sangat Tinggi \\
$70,00 \%<x \leq 85,00 \%$ & Tinggi \\
$55,00 \%<x \leq 70,00 \%$ & Cukup \\
$40,00 \%<x \leq 55,00 \%$ & Rendah \\
\hline $00,00 \%<x \leq 40,00 \%$ & Sangat Rendah \\
\hline
\end{tabular}

\section{HASIL DAN PEMBAHASAN.}

\section{Hasil}

\section{Siklus Pertama}

Pelaksanaan siklus I Pertemuan 1 dilaksanakan pada hari Jum'at tanggal 8 April 2016 di SMP Negeri 4 Blitar pada jam pertama, kedua dan ketiga. Pertemuan berlangsung $3 \times 40$ menit dilaksanakan pada jadwal terstruktur. Proses belajar mengajar mengacu pada rencana pembelajaran yang telah dipersiapkan. Pengamatan (observasi) dilaksanakan bersamaan dengan pelaksaaan belajar mengajar.

Langkah yang dilakukan antara lain adalah menyiapkan instrumen penelitian, dan bahan ajar salah satunya rencana pelaksanaan pembelajaran Siklus I, soal-soal, tugas kelompok, post-test, lembar observasi dan jurnal kegiatan. Menyiapkan evaluasi beserta kunci jawabannya, evaluasi digunakan peneliti untuk mengukur sejauh mana keberhasilan proses pembelajaran. Menyiapkan lembar observasi, untuk mengamati proses pembelajaran.

Kegiatan diawali dengan menjelaskan tentang metode yang akan digunakan yaitu pembelajaran direct instructions dan komponen-komponennya kepada siswa. Guru membuka pelajaran dengan mengucapkan salam, menanyakan tentang kesehatan siswa secara umum memeriksa seragam siswa dan dilanjutkan pembagian kelompok. Setiap kelompok terdiri dari 8 siswa. Guru menjelaskan tentang teknik-teknik menendang bola mulai dari teknik menendang bola dengan kaki bagian balam,bagian luar, punggung kaki, punggung kaki bagian luar dan punggung kaki bagian dalam, selesai penjelasan diberikan kesempatan pada siswa untuk mengajukan pertanyaan,karena tidak ada pertanyaan dari siswa maka siswa diajak untuk ke lapangan mengamati demonstrasi dari guru tentang teknik menendang bola dengan berbagai teknik. Selanjutnya siswa diberi kesempatan untuk melakukan tendangan sesuai dengan teknik yang telah diajarkan bersama kelompok masing-masing. Semua kelompok dianggap sudah cukup dalam melakukan tendangan maka semua kelompok berkumpul kembali dan diadakan pemantapan tentang materi teknik menendang bola dan menyampaian materi minggu depan. Dilanjutkan dengan post-test.

Observasi kegiatan siswa dilaksanakan saat proses pembelajaran Penjaskes berlangsung. Guru mengamati jalannya pembelajaran. Pertama, guru mengamati jumlah siswa, untuk dapat dibagi menjadi beberapa kelompok. Kedua, guru mengamati langkah-langkah kegiatan siswa ketika melaksanakan kegiatan pembelajaran, sudah sesuai dengan langkah yang ditempuh siswa. Ketiga, guru mengamati keaktifan siswa saat melaksanakan percobaan.

Melalui pengumpulan data, nilai ulangan harian tentang sepakbolarata-rata nilai yang didapat kurang dari Kriteria Ketuntasan Minimal (KKM) telah ditentukan sebesar 75. Nilai harian Penjaskes materi dan teknik-teknik gerakan sepak bola berdasarkan: nilai afektif, dari hasil pengamatan awal pembelajaran didapat dari 34 siswa ada 2 siswa yang belum melakukan doa dengan baik, 32 siswa sudah melakukan doa dengan baik. Jika dipersentase ada 94,11\% siswa yang melakukan doa dengan baik dan pada saat akhir pelajaran 34 siswa dari 34 siswa yang sudah melakukan doa. Berarti jika dipersentase ada 100\%. Dari hasil pengamatan Nilai ketrampilan dari jumlah 34 siswa hanya 12 siswa yang telah melakukan gerakan menendang bola dengan benar.22 siswa belum dapat melakukan tendangan dengan benar.Dari hasil pengamatan jika dipersentase ada 35,29\%, dari hasil ulangan harian hanya 15 siswa dari 34 siswa yang mendapat nilai di atas KKM. Analisis soal yang telah dilakukan menunjukkan bahwa kesulitan paling banyak dialami siswa dalam memperagakan teknik-teknik sepak bola adalah menerangkan teknik-teknik sepak bola tersebut dengan benar. Berdasarkan perhitungan nilai 
ulangan harian ada $44,11 \%$ siswa yang mencapai nilai di atas KKM 75. Melihat kondisi awal di atas, maka penerapan metode pembelajaran direct instructions, siswa kelas VII-B SMP Negeri 4 Blitar Tahun Pelajaran 2015/2016 pada pertemuan ke 2 diharapkan dapat mengatasi kesulitan belajar dan menguasai materi dan teknik-teknik tentang sepak bola dengan benar.

Pelaksanaan siklus I Pertemuan ke 2 dilaksanakan pada hari Jum'at tanggal 15 April 2016 di SMP Negeri 4 Blitar pada jam pertama, kedua dan ketiga. Pertemuan berlangsung $3 \times 40$ menit dilaksanakan pada jadwal terstruktur. Proses belajar mengajar mengacu pada rencana pembelajaran yang telah dipersiapkan. Pengamatan (observasi) dilaksanakan bersamaan dengan pelaksaaan belajar mengajar.

Langkah peneliti antara lain adalah menyiapkan instrumen penelitian, dan bahan ajar salah satunya rencana pelaksanaan pembelajaran Siklus I materi pelajaran Penjaskes kelas VII-B semester 2. Mempersiapkan soal-soal, tugas kelompok, post test, lembar observasi. Menyiapkan evaluasi beserta kunci jawabannya, evaluasi digunakan peneliti untuk mengukur sejauh mana keberhasilan proses pembelajaran. Menyiapkan lembar observasi, untuk mengamati proses pembelajaran.

Kegiatan diawali dengan menjelaskan tentang metode yang akan digunakan yaitu pembelajaran direct instructions dan komponen-komponennya kepada siswa. Guru membuka pelajaran dengan mengucapkan salam, menanyakan tentang kesehatan siswa secara umum memeriksa seragam siswa dan dilanjutkan pembagian kelompok. Guru menjelaskan tentang teknik-teknik menghentikan bola mulai dari teknik menghentikan bola dengan kaki bagian balam ,bagian luar, punggung kaki, punggung kaki bagian luar dan punggung kaki bagian dalam, siswa diajak ke lapangan untuk mengamati demonstrasi dari guru tentang teknik menghentikan bola dengan berbagai teknik. Berdasarkan pengamatan demonstrasi dari guru tentang teknik menghentikan bola kiranya siswa sudah memahami. Selanjutnya siswa diberi kesempatan untuk mencoba menghentikan bola dengan berbagaiteknik yang telah diajarkan bersama kelompok masing-masing. Semua kelompok dianggap sudah cukup dalam melakukan teknik menghentikan bola maka semua kelompok berkumpul kembali. Dilanjutkan dengan post-test.

Observasi kegiatan siswa dilaksanakan saat proses pembelajaran Penjaskes berlangsung. Kegiatan observasi difokuskan pada pelaksanaan pembelajaran.Guru mengamati langkah-langkah kegiatan siswa ketika melaksanakan kegiatan pembelajaran, sudah sesuaikah langkah yang ditempuh siswa. Guru mengamati keaktifan siswa saat melaksanakan percobaan.

Melalui gumpulan data, rata-rata nilai harian Penjaskes materi dan teknik-teknik gerakan sepak bola berdasarkannilai afektifdari hasil pengamatan dari 34 siswa ada 4 siswa yang belum melakukan kerjasama dengan baik, 30 siswa sudah melakukan kerjasama dengan baik. Jika dipersentase ada $88,23 \%$ siswa yang melakukan kerjasama dengan baik. Lewat hasil pengamatan nilai ketrampilan dari jumlah 34 siswa hanya 22 siswa yang telah melakukan gerakan menghentikan bola dengan benar, 12 siswa masih belum bisa melakukan teknik menghentikan bola dengan benar. Jika di prosentase ada $64,70 \%$ siswa yang telah melakukan teknik menghentikan bola dengan benar. Dari hasil nilai ulangan harian Penjaskes materi dan teknik-teknik gerakan menghentikan bola, dengan nilai KKM sebesar 75: hanya 21 siswa yang mendapat nilai di atas KKM.Analisis soal yang telah dilakukan menunjukkan bahwa kesulitan paling banyak dialami adalah teknik-teknik menghentikan bola tersebut dengan benar. Dari perhitungan nilai ulangan harian ada $61,76 \%$ siswa yang mencapai nilai di atas KKM 75.

Untuk pelaksanaan pembelajaran, guru masih menghadapi berbagai kendala, antara lain: beberapa siswa masih tampak gaduh saat guru menjelaskan materi.Masih ada kelompok yang bingung dalam mengikuti langkah-langkah yang tertera dalam lembar kegiatan. Masih ada beberapa siswa yang belum aktif dalam pelaksanaan percobaan. Masih terdapat beberapa siswa yang hanya bermain-main saat kegiatan pembelajaran berlangsung, ada beberapa siswa yang tidak aktif menyampaikan pendapatnya. Dapat disimpulkan hasil pada pertemuan 1 terdapat nilai afektif terdapat $94,11 \%$,nilai ketrampilan terdapat $35,29 \%$ nilai ulangan harian $44,11 \%$ pada pertemuan ke dua afektif terdapat $88,23 \%$,ketrampilan terdapat $60,70 \%$ ulangan harian terdapat $61,76 \%$.Dari hasil 
diatas dapat kita simpulkan ada kenaikan dari hasil belajar siswa dari pertemuan 1 dengan pertemuan 2. Namun karena belum mencapai target indikator pencapaian siklus I sebesar $85 \%$ atau lebih, maka akan dilanjutkan ke Siklus II.

\section{Siklus Kedua}

Pelaksanaan siklus 2 Pertemuan 1 dilaksanakan pada hari Jum'at tanggal 22 April 2016 di SMP Negeri 4 Blitar pada jam pertama, kedua dan ketiga. Pertemuan berlangsung 3x40 menit dilaksanakan pada jadwal terstruktur. Proses belajar mengajar mengacu pada rencana pembelajaran yang telah dipersiapkan. Pengamatan (observasi) dilaksanakan bersamaan dengan pelaksaaan belajar mengajar.

Langkah peneliti antara lain adalah menyiapkan instrumen penelitian, dan bahan ajar salah satunya rencana pelaksanaan pembelajaran siklus 2 materi pelajaran Penjaskes kelas VII-B semester 2. Mempersiapkan pula soal-soal, tugas kelompok, post test, lembar observasi dan jurnal kegiatan. Menyiapkan evaluasi beserta kunci jawabannya, evaluasi digunakan peneliti untuk mengukur sejauh mana keberhasilan proses pembelajaran. Menyiapkan lembar observasi, untuk mengamati proses pembelajaran.

Kegiatan diawali dengan menjelaskan tentang metode yang akan digunakan yaitu pembelajaran direct instructions dan komponen-komponennya kepada siswa. Guru membuka pelajaran dengan mengucapkan salam, menanyakan tentang kesehatan siswa secara umum memeriksa seragam siswa dan dilanjutkan pembagian kelompok. Guru menjelaskan tentang teknik-teknik menggiring bola dengan kaki bagian dalam,bagian luar,selesai penjelasan siswa diajak untuk ke lapangan mengamati demonstrasi dari guru tentang teknik menggiring bola dengan berbagai teknik. Selanjutnya siswa diberi kesempatan untuk melakukan gerakan menggiring bola sesuai dengan teknik yang telah diajarkan bersama kelompok masing-masing.Semua kelompok dianggap sudah cukup dalam melakukan gerakan menggiring bola maka semua kelompok berkumpul kembali dan dilanjutkan dengan post tes

Kegiatan observasi dilaksanakan saat proses pembelajaran Penjaskes berlangsung. Kegiatan observasi difokuskan pada pelaksanaan pembelajaran. Kedua, Guru mengamati langkahlangkah kegiatan siswa ketika melaksanakan kegiatan pembelajaran. Ketiga, Guru mengamati keaktifan siswa saat melaksanakan gerakan menggiring bola.Dari pengumpulan data, nilai afaktif,nilai ketrampilan dan nilai ulangan harian tentang teknik menggiring bola sebagai berikut: nilai afektif, dengan melalui pengamatan maka dari 34 siswa ada 4 siswa yang belum merasa percaya punya kemampuan dengan baik, 30 siswa sudah nampak percaya dengan baik. Ada $88,23 \%$ siswa yang sudah nampak percaya diri. Nilai ketrampilan,dengan melalui pengamatan dari jumlah 34 siswa terdapat 28 siswa yang telah melakukan gerakan menggiring bola dengan benar. 6 siswa masih belum melakukan teknik menggiring bola dengan benar,jika dihitung prosentase ada $82,35 \%$ siswa yang sudah melakukan dengan benar. Berdasarkan hasil nilai ulangan harian ada 27 siswa. Melalui perhitungan nilai ulangan harian ada $79,41 \%$ siswa yang mencapai nilai di atas KKM 75.

Berdasarkan kondisi di atas, maka penerapan metode pembelajaran direct instructions, siswa kelas VII-B SMP Negeri 4 Blitar tahun pelajaran 2015/2016 pada pertemuan ke 2 diharapkan dapat mengatasi kesulitan belajar dan menguasai materi dan teknik-teknik tentang sepak bola dengan benar.

Pelaksanaan siklus 2 Pertemuan ke 2 dilaksanakan pada hari Jum'at tanggal 29 April 2016 di SMP Negeri 4 Blitar pada jam pertama, kedua dan ketiga. Pertemuan berlangsung $3 \times 40$ menit dilaksanakan pada jadwal terstruktur. Proses belajar mengajar mengacu pada rencana pembelajaran yang telah dipersiapkan. Pengamatan (observasi) dilaksanakan bersamaan dengan pelaksaaan belajar mengajar

Langkah yang dilakukan adalah menyiapkan instrumen penelitian, dan bahan ajar salah satunya Rencana Pelaksanaan Pembelajaran Siklus 2. Mempersiapkan soal-soal, tugas kelompok, post test, lembar observasi.Menyiapkan evaluasi beserta kunci jawabannya, evaluasi digunakan peneliti untuk mengukur sejauh mana keberhasilan proses pembelajaran. Menyiapkan lembar observasi, untuk mengamati proses pembelajaran.

Kegiatan diawali dengan menjelaskan tentang metode yang akan digunakan yaitu pembelajaran direct instructions dan komponen-komponennya 
kepada siswa. Guru membuka pelajaran dengan mengucapkan salam, menanyakan tentang kesehatan siswa secara umum memeriksa seragam siswa dan dilanjutkan pembagian kelompok. Guru menjelaskan tentang teknik-teknik menggiring bola dengan punggung kaki,selesai penjelasan siswa diajak ke lapangan untuk mengamati demonstrasi dari guru tentang teknik menggiring bola dengan berbagai teknik. Dari pengamatan demonstrasi dari guru tentang teknik menggiring bola kiranya siswa sudah memahami. Selanjutnya siswa diberi kesempatan untuk mencoba mengg iring bola dengan kaki bagian luar dan punggung kaki yang telah diajarkan bersama kelompok masing-masing. Semua kelompok dianggap sudah cukup dalam melakukan teknik menggiring bola maka semua kelompok berkumpul kembali dan dilanjutkan dengan post-test.

Kegiatan observasi dilaksanakan saat proses pembelajaran Penjaskes berlangsung. Kegiatan observasi difokuskan pada pelaksanaan pembelajaran. Dalam kegiatan ini, guru mengamati jalannya pembelajaran. Pertama,guru mengamati kelengkapan siswa, untuk dapat dibagi menjadi beberapa kelompok. Kedua, guru mengamati langkah-langkah kegiatan siswa ketika melaksanakan kegiatan pembelajaran.Ketiga, guru mengamati keaktifan siswa saat melaksanakan percobaan.

Berdasarkan hasil pengamatan nilai afektif didapat dari 34 siswa ada 2 siswa yang belum melakukan kerjasama dengan baik, 32 siswa sudah melakukan kerjasama dengan baik. Jika dipersentase ada 94,11\% siswa sudah melakukan kerjasama dengan baik.Nilai Ketrampilan: dari jumlah 34 siswa 32 siswa telah melakukan gerakan menggiring bola dengan benar, 2 siswa masih belum melakukan gerakan menggiring bola dengan benar. Jadi pada pertemuan ke 2 siklus 2 siswa yang melakukan gerakan menggiring bola dengan benar 94,11\%. Dari hasil ulangan harian 31 siswa telah mendapat nilai di atas KKM.Dari perhitungan nilai ulangan harian ada 91,17\% siswa yang mencapai nilai di atas KKM 75. Berdasarkan kondisi di atas, maka penerapan metode pembelajaran direct instructions, siswa kelas VII-B SMP Negeri 4 Blitar tahun pelajaran 2015/2016 pada pertemuan ke 2dapat mengatasi kesulitan belajar dan menguasai materi dan teknikteknik tentang sepak bola dengan benar.

Untuk pelaksanaan proses pembelajaran, guru telah melaksanakan perbaikan dari siklus I, siswa sudah mengalami kemajuan dan pelaksanaanpun telah berjalan baik. Adapun prosentase hasil observasi dalam pelaksanaan percobaan pada siklus II dapat dilihat dari perhitungan prosentase keberhasilan siklus II. Hasil post-test pada siklus kedua dapat menjadi perhitungan persentase peningkatan prestasi belajar siswa. Dengan acuan penilaian tetap berdasarkan nilai KKM yang telah ditetapkan yaitu paling sedikit siswa memperoleh nilai 75. Adapun rekapitulasi hasil rata-rata test siklus 2 berdasarkan penilaian :

Nilai Afektif pertemuan 1 siklus 2 : 88,23\% sedangkan pada pertemuan $2: 94,11 \%$. Nilai Ketrampilan pertemuan 1 siklus 2: 82,35\%, sedangkan pada pertemuan $2: 94,11 \%$. Nilai pengetahuan pertemuan 1 siklus 2 : 79,41\%, sedangkan pada pertemuan 2: 91,17\%. Nilai $\mathrm{KKM}=75$. Jadi sudah ada peningkatan prestasi belajar yang signifikan. Telah mencapai indicator pencapaian siklus II sebesar $85 \%$.

Selain itu, dari proses wawancara diperoleh kesimpulan bahwa beberapa siswa menjadi bersemangat dalam mempelajari materi dan teknik-teknik sepak bola, karena pelaksanaan kegiatan belajar Penjaskes dengan pembelajaran direct instructions ini dilaksanakan dengan saling membantu dan bekerja sama antar siswa, sehingga mereka lebih efektif dan ringan dalam melaksanakan kegiatan.

\section{Pembahasan}

Berdasarkan hasil pelaksanaan pada siklus I, II dapat dinyatakan bahwa terjadi peningkatan kualitas pembelajaran yang tampak dan perolehan hasil evaluasi dan keaktifan siswa.Ketika peneliti melaksanakan siklus I, peneliti mengalami berbagai kendala antara lain beberapa siswa masih tampak melakukan kegiatan sepak bola berdasarkan apa yang mereka ketahui bukan berdasarkan materi dan teknik yang diajarkan. Masih ada kelompok yang bingung dalam mengikuti langkah-langkah yang tertera dalam lembar kegiatan. Masih ada beberapa siswa yang belum aktif dalam pelaksanaan percobaan, ada beberapa siswa yang 
tidak aktif menyampaikan pendapatnya. Untuk hasil percobaan dapat disimpulkan bahwa, masih banyak siswa yang malu untuk bertanya, dan ikut memeragakan teknik-teknik sepak bola yang diajarkan.

Kemudian melaksanakan siklus II sebagai perbaikan siklus I, sebelum pelaksanaan siklus II ini peneliti melengkapi rencana pembelajaran yaitu siswa yang telah menguasai materi dan teknik-teknik sepak bola pada siklus 1 dipasangkan dengan siswa yang belum memahami materi dan teknik-teknik sepak bola untuk saling membantu dan bekerjasama dalam melaksanakan kegiatan pembelajaran.

Untuk pelaksanaan percobaan, guru senantiasa memberikan bimbingan untuk siswanya dalam melaksanakan langkah-langkah sesuai lembar kegiatan. Trianto (2007:73) bahwa tugas interaktif seorang guru adalah orientasi siswa pada masalah, mengorganisasikan siswa untuk belajar, membantu penyelidikan invidual dan kelompok serta analisis dan evaluasi proses pemecahan masalah.Memberibimbingan siswa saat berdiskusi untuk menarik kesimpulan. Adanya motivasi guru berupa reward, siswa sudah berani saling berebut untuk bertanya dan berpartsisipasi aktif. Menurut Hayinah (1992) yang menyatakan motivasi instrinsik siswa dalam belajar salah satunya dengan adanya keinginan untk mencapai prestasi sehingga mendapat dukungan dari orangorang penting, seperti orangtua, saudara, guru, atau teman-temannya.Mereka tampak antusias dalam merebutkan prestasi belajar yang baik.

Berdasarkan daftar nilai dapat kita lihat adanya prosentase kenaikan nilai Penjaskes mulai dari pertemuan 1 siklus 1 sampai pertemuan 2 siklus2,dapat dilihat pada Tabel2.

Hal itu menunjukkan bahwa pelaksanaan siklus I belum mencapai keberhasilan karena indikator pencapaianrnya adalah sebesar $85 \%$. Siklus II menunjukkan ada 31 siswa atau 91,17\% dari 34 siswa yang mengalami ketuntasan belajar. Sehingga peneliti menyimpulkan bahwa pada siklus II ini peneliti telah mencapai keberhasilan dari penelitian tindakan kelas yang telah dilakukan. Dari hasil belajar yang dicapai dapat disimpulkan bahwa penelitian tindakan kelas dari siklus II ini telah berhasil.

Peningkatan hasil belajar siswa ditentukan beberapa faktor yang sangat mempengaruhi. Syah (2003:154) menyatakan dalam peningkatan prestasi belajar peserta didik, ada banyak faktor yang mempengaruhinya, baik faktor dalam (internal) maupun faktor dari luar (eksternal). Faktor internal meliputi intelegensi, motivasi dan kondisi kesehatan.Faktor eksternal meliputi lingkungan keluarga, sarana dan prasarana disekolah, dan kemampuan guru. Setiap faktor akan mempengaruhi kualitas proses dan prestasi belajar. Melalui penelitian ini, diketahui bahwa kemampuan guru dalam meningkatkan belajar siswa disamping dengan pemberian motivasi belajar untuk siswa.Salah satunya kemampuan guru dalam menerapkan model pembelajaran direct intructions.Model Pengajaran Langsung (direct intructions) merupakan suatu pendekatan mengajar yang dapat membantu siswa dalam mempelajari keterampilan dasar dan memperoleh informasi yang dapat diajarkan selangkah demi selangkah. Pendekatan mengajar ini sering disebut Model Pengajaran Langsung (Kardi dan Nur, 2000:2). Hal ini menunjukkan model pembelajaran direct intructions mampu meningkatkan hasil pelajar siswa dalam mata pelajaran Penjaskes, khususnya mengenai materi teknik-teknik menendang bola dengan pembelajaran teoritis dan praktis.

Tabel 2 Prosentase Kenaikan Nilai Penjaskes

\begin{tabular}{cccccc}
\hline \multirow{2}{*}{ No } & Aspek yang Dinilai & \multicolumn{2}{c}{ Siklus 1 } & \multicolumn{2}{c}{ Siklus 2 } \\
\cline { 3 - 6 } & & Pertemuan1 & Pertemuan2 & Pertemuan 1 & Pertemuan 2 \\
\hline 1 & Sikap & $94,11 \%$ & $88,23 \%$ & $88,23 \%$ & $94,11 \%$ \\
2 & Ketrampilan & $35,29 \%$ & $64,70 \%$ & $82,35 \%$ & $94,11 \%$ \\
3 & Pengetahuan & $44,11 \%$ & $61,76 \%$ & $79,41 \%$ & $91,41 \%$ \\
\hline
\end{tabular}




\section{KESIMPULAN DAN SARAN}

\section{Kesimpulan}

Berdasarkan hasil observasi dan pelaksanaan siklus I dan II dapat kita amati adanya perubahan kenaikan prosentase diantaranya menyiapkan alat dan bahan, keruntutan langkah-langkah siswa dalam melaksanakan percobaan, keaktifan siswa dalam melaksanakan kegiatan percobaan, keaktifan siswa ketika berdiskusi dan hasil akhir . Hal ini dapat dilihat dari prosentase kenaikan nilai Penjaskes siswa kelas VII-B dari, siklus I sampai Siklus II. Pada siklus I siswa yang mendapat nilai minimal 75 ada 21 siswa atau $61,76 \%$, pada siklus II siswa yang mendapat nilai minimal 75 ada 31 siswa atau $91,17 \%$ dari 34 siswa. Siklus I kemudian dilaksanakan siklus II hasil belajar siswa mengalami kenaikan prosentase $29,41 \%$.

\section{Saran}

Berdasarkan hasil penelitian, maka ada beberapa saran yang dapat dipergunakan sebagai bahan pertimbangan. Hendaknya mempersiapkan secara cermat perangkat pendukung pembelajaran dan fasilitas belajar yang diperlukan, karena sangat mempengaruhi efektivitas dan efisiensi pembelajaran yang pada akhirnya berpengaruh pada proses dan hasil belajar siswa. Guru juga harus memahami dan memvariasikan metode yang sesuai materi yang dapat digunakan dalam proses pembelajaran, sehingga hasil siswa dapat meningkat.

\section{DAFTAR RUJUKAN}

Hayinah. 1992. Masalah Belajar. Malang: DepDikbud IKIP Negeri Malang.

Kardi, S \& Nur, M. 2000. Pengajaran Langsung. Surabaya: Universitas Negeri Surabaya University Press.

Sucipto, dkk. 2000. Sepakbola. Jakarta: Departemen Pendidikan dan Kebudayaan.

Sukintaka.1992. Teori Bermain untuk D2 PGSD Penjaskes. Jakarta: DepartemenPendidikan dan Kebudayaan Dirjen Dikti Proyek Pembinaan Tenaga Pendidikan.

Syah, M. 2003. Psikologi Belajar. Jakarta: PT. Raja Grafindo Persada.

Trianto. 2007. Model-model Pembelajaran Inovatif Berorientasi Konstruktivistik. Jakarta: Prestasi Pustaka. 